\title{
Ant nests and soil nutrient availability: the negative impact of fire
}

\author{
Leandro Sousa-Souto*1, José H. Schoereder†, Carlos Ernesto G. R. Schaeferł \\ and Washington L. Silva $\S$
}

\author{
* Departamento de Biologia Animal, Universidade Federal de Viçosa, Brazil, 36570-000 \\ $\dagger$ Departamento de Biologia Geral, Universidade Federal de Viçosa, Brazil, 36570-000 \\ $\ddagger$ Departamento de Solos, Universidade Federal de Viçosa, Brazil, 36570-000 \\ $\S$ Laboratório de Ecologia de Comunidades, Universidade Federal de Viçosa, Brazil, 36570-000 \\ (Accepted 5 September 2008)
}

\begin{abstract}
High-nutrient patches are important for regulating the structure and physiognomy of dystrophic habitats. Leaf-cutting ants create these rich patches in many neotropical habitats. Burning, however, could diminish or even annul the effects of ant nests on soil properties. To test this hypothesis, we compared the nutrient concentrations at various depths in soil samples near three nests of the leaf-cutting ant Atta laevigata and three non-nest soils, located in 10-ha plots subjected to burning or with fire-protection within a Brazilian cerrado. Root density in ant-nest soil was greater than in non-nest soil in both unburned and burned plots. Besides, the concentration of $\mathrm{Ca}, \mathrm{Mg}$, $\mathrm{K}$ and $\mathrm{P}$ increased 2-50-fold in ant nests from the unburned area compared to non-nest soils. In contrast, nutrient concentrations and $\mathrm{pH}$ in burned ant nests were similar to or lower than non-nest soils, but the nests maintained higher values of organic matter and cation exchange capacity. The positive effect of leaf-cutting ant nests as high-nutrient patches may be strongly reduced in habitats with frequent burning. In this case, the negative effects of leaf-cutter herbivory on a plant community could surpass the benefits of local nutrient enrichment by their nests.
\end{abstract}

Key Words: Atta laevigata, leaf-cutting ants, root density, savanna, soil organic matter

Resumo: Sauveiros modificam as propriedades físicas e químicas do solo, alterando a estrutura e fisionomia local. Entretanto, queimadas podem reduzir os efeitos dos formigueiros nesses ambientes como, por exemplo, pela diminuição do forrageamento das formigas e, conseqüentemente, pela baixa incorporação de material orgânico ao solo. Este estudo testou o efeito do fogo sobre a concentração de nutrientes no solo de colônias de Atta laevigata em área de cerrado. A densidade de raízes foi maior nas colônias do que áreas controle, independentemente da presença do fogo. Na ausência de queimadas, as concentrações de nutrientes foram até 50 vezes superiores nos sauveiros. Contudo, queimadas reduzem a concentração de nutrientes e pH nas colônias. Possivelmente, essa baixa concentração seja atribuída à maior demanda pela vegetação remanescente, em resposta à perturbação provocada pelo fogo. Nesse caso, os efeitos negativos da herbivoria podem superar os benefícios causados por meio da disponibilização de nutrientes pelos sauveiros.

\section{INTRODUCTION}

Nutrient availability is of critical importance for the physiognomy, functioning and structure of dystrophic habitats. The availability of nutrients is limited in many tropical ecosystems, varying with locality and with regional factors such as climate, species composition and succession. In these habitats, the activity of soil fauna is of primary importance for soil nutrient availability

\footnotetext{
${ }^{1}$ Corresponding author. Present address: Departamento de Biologia Laboratório de Entomologia, Universidade Federal de Sergipe, Brazil, 49100-000. Email: leandrosouto@insecta.ufv.br
}

(Lobry de Bruyn \& Conacher 1990, van de Vijver et al. 1999, Wood \& Sands 1978). Through nest activities, several species of ant and termite promote local concentrations of organic matter in their nests, creating nutrient-rich patches.

An important group of soil fauna in Neotropical ecosystems are leaf-cutting ants of the genus Atta and Acromyrmex (Hymenoptera: Formicidae) (Araújo et al. 1997, Cherrett 1989). These ants have a large impact on the vegetation, both as herbivores and as soil modifiers (Cherrett 1989, Lobry de Bruyn \& Conacher 1990). For example, ant nests play an important role in the formation of local patterns of vegetation by facilitating seed recruitment and plant establishment, and 
increasing root biomass (Farji-Brener \& Medina 2000, Garrettson et al. 1998). Ants change the soil through (1) inversion of soil layers through nest excavation and (2) mineralization and release of nutrients from the organic matter dumped in nest chambers containing fungus gardens and through partial mineralization of the refuse dumped inside or outside the nests, thus creating high-nutrient patches (Cherrett 1989, FarjiBrener \& Illes 2000, Haines 1978, Moutinho et al. 2003). Recent studies show that plants surrounding leafcutting ant nests directly use accumulated nutrients from these patches (Sousa-Souto et al. 2007, Sternberg et al. 2007).

Savanna-type habitats, collectively known as cerrado, occupy an area of about $1800000 \mathrm{~km}^{2}$ in Central Brazil and represent the second largest biome formation in the country after tropical rain forests. The Brazilian cerrado comprises a complex vegetation mosaic of savannas, grasslands and dry forests. Although these physiognomies have been classified into five groups according mainly to their tree densities (Coutinho 1978), they often occur intermingled in the same area, and several factors are responsible for the determination of the local vegetation, such as soil moisture, soil nutritional status and the effects of fire and leaf-cutting ants (Coutinho 1978, 1984).

Burning is a common and widespread disturbance factor, occurring every 1-5 y (Coutinho 1978, Eiten 1972). On the one hand, frequent fires create vegetation gaps and may facilitate the establishment of leaf-cutting ants, which prefer open areas, so that recently disturbed areas invariably have high nest densities (Rao 2000, Schoereder \& Coutinho 1990, Vasconcelos \& Cherrett 1995). On the other hand, burning has a negative impact on plant diversity and composition (Moreira 2000) and can affect foraging activity of leaf-cutting ants (Araújo et al. 2004). In the long term, reduced plant diversity could limit the range of species harvested by leaf-cutting ants and could consequently decrease the amount of organic matter accumulated within nests as well as its mineralization. In this case, the negative effect of herbivory by leaf-cutting ants, which may cause an energetic loss to the plant community (Cherrett 1989, Lugo et al. 1973), could surpass the positive effect of nests as high-nutrient patches (Farji-Brener \& Illes 2000, Moutinho et al. 2003).

We tested the hypothesis that the occurrence of fire has a negative effect on nutrient availability in soils from nests of the leaf-cutting ant Atta laevigata (F. Smith, 1858). In addition, we measured the vertical density of roots (diameter $>2 \mathrm{~mm}$ ) inside ant nests and in nonnest areas to verify if plants close to ant nests could access the available nutrients in the soil beneath the nests.

\section{METHODS}

\section{Study site}

The study was conducted at the Ecological Reserve of the Brazilian Institute of Geography and Statistics (RECOR-

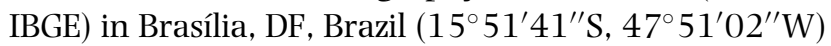
within the experimental area of a large fire project. This reserve covers 1375 ha within a slightly hilly landscape (1130-1160 m asl). The mean annual rainfall is $1478 \mathrm{~mm}$ with a well-defined dry season from May to September and a mean annual temperature of around $21{ }^{\circ} \mathrm{C}$. The native vegetation is characterized as cerrado, with physiognomic forms ranging from grasslands to savanna woodland and low forest 'cerradão' (Coutinho 1978). The dominant soil type is a deep well-drained red latosol (oxisol), with high clay content, mostly kaolinite, a low cation exchange capacity and moderate acidity $(\mathrm{pH}$ range: 4.5-6.2), derived from Tertiary lateritic deposits (Embrapa 1999). The fire project consists of 30 plots of 4-10 ha, distributed over several savanna physiognomies (from grasslands to cerradão woodland) and subjected to different fire disturbance. The prescribed burns in the fire project were similar in regime and intensity to natural burns in the region of study (Miranda et al. 1993).

The effect of fires on soil nutrient concentrations of $A$. laevigata nests was tested using a 10-ha burned and a 10-ha unburned plot in a cerrado denso vegetation type. Cerrado denso is a dense savanna where trees predominate; the woody cover varies between $50-70 \%$ and the average tree height is between 5 and $8 \mathrm{~m}$ (Coutinho 1978, Eiten 1972). The burned plot had been subjected to burning every 2 y since 1992 , and was burnt $30 \mathrm{~d}$ before this study. The unburned plot was protected from fire since 1974 (Miranda et al. 1993).

The plots were chosen because they had relatively large ant colonies, covered with some woody plants, thus allowing us to access root density at several depths either inside ant nests or non-nest areas. The plots were surveyed for mature A. laevigata nests (covering $>4 \mathrm{~m}^{2}$ ) from March to April 2004, both at the margin of the plot and inside it. The nests were classified as either active or abandoned. We limited our study to active nests only, which were characterized by the presence of ants (most cases), recently cut leaves dropped on the nest-mound, well-maintained foraging trails, or recent signs of soil disturbance.

\section{Soil samples and chemical analyses}

Shafts $(1 \times 1 \times 2 \mathrm{~m}$ deep $)$ were manually excavated in July 2004 (during the dry season) at the highest point of three nest mounds and at a minimum distance of $25 \mathrm{~m}$ from the edge of each nest mound (control soil), 
in both burned and unburned plots (methods adapted from Moutinho et al. 2003). The three largest ant colonies found in the unburned plot and in the burned plot were chosen for excavation. Such large nests should have a more detectable effect on the soil properties than smaller nests because they have chambers at deeper soil levels. In each of 12 excavated shafts (six replicates for nests and six for non-nest soils), soil samples were taken at several depths $(0-40,40-80,80-120,120-160$ and at 200 and $350 \mathrm{~cm}$ ). The soil sample at $350 \mathrm{~cm}$ depth was collected using an 8-cm-diameter core auger (extension $1.5 \mathrm{~m}$ ). In the nest shafts, samples were taken avoiding fungus and refuse chambers. Soil samples were air-dried at $50{ }^{\circ} \mathrm{C}$ for $48 \mathrm{~h}$. The concentrations of the macronutrients $\mathrm{K}, \mathrm{Ca} \mathrm{Mg}$ and $\mathrm{P}$ were determined. In addition, we measured the $\mathrm{pH}$, organic carbon (OC) and cation exchange capacity (CEC), following Embrapa (1997). Chemical analyses included soil $\mathrm{pH}$ in water in a 1:2.5 soil mass:solution volume ratio, total exchangeable $\mathrm{K}$, Ca and $\mathrm{Mg}$ were determined after extraction with $1 \mathrm{M} \mathrm{NH}_{4} \mathrm{Cl}$ (Embrapa 1997), $\mathrm{P}$ was measured with a Mehlich I extractant and the organic carbon (OC) was determined following the Walkley-Black method $(\mathrm{OM}=\mathrm{OC} \times 1.724)($ Embrapa 1997). The cation exchange capacity (CEC) was measured in $5 \mathrm{~g}$ of soil with ammonium acetate at pH 7 (Embrapa 1997). High CEC values indicate elevated soil fertility. Total soil nitrogen was not determined due to possible losses during handling and high variability due to low amounts in these soils, with a range of concentration typically between 0.03 and $0.30 \%$ (Embrapa 1999). In our study site, nitrogen is not a limiting nutrient for plants (Sousa-Souto et al. 2007). Moreover, recent studies have found that leaf-cutting ant nests did not alter total $\mathrm{N}$, net $\mathrm{N}$ mineralization rates or net $\mathrm{N}$ nitrification at depth in a well-drained red latosol (oxisol) (Moutinho et al. 2003, Verchot et al. 2003).

\section{Vertical density of roots}

We measured the vertical density of coarse roots (diameter $>2 \mathrm{~mm}$ ) in the 12 excavated shafts using a rectangular transect $(50 \times 40 \mathrm{~cm})$ with 80 subdivisions of $5 \mathrm{~cm}$. The rectangular transect was used in the shaft walls and the proportion of subdivisions occupied with roots was measured at depth intervals of 0-40, 40-80, 80-120, $120-160$ and $160-200 \mathrm{~cm}$, excluding the nest mound. As the sampled plots comprise a dense savanna where trees predominate, the distance of ant nests to surrounding plants was negligible.

\section{Statistical analysis}

All analyses were done using $\mathrm{R}$ (R Development Core Team., R Foundation for Statistical Computing, Vienna,
Austria. http://www.R-project.org), using linear mixedeffects models (lme) with binomial error, followed by analysis of residuals to check for the suitability of error distribution and for model adjustment. Minimum adequate models (MAM) were obtained by deleting non-significant terms $(\mathrm{P}<0.05)$ from the full model consisting of all variables and their interactions. Soil depth was added as the random factor in all complete models (Crawley 2002).

The proportion of small squares occupied by roots across soil depth was compared using the proportion of roots as the response variable, with shaft location (ant nest; non-nest; ant nest from burned area; non-nest from burned area), soil depth, and the interaction shaft location $\times$ soil depth as factors, with binomial error distribution.

We compared concentrations of $\mathrm{Ca}, \mathrm{Mg}, \mathrm{K}, \mathrm{P}, \mathrm{pH}$, organic matter (OM) or CEC with the same factors as mentioned above, with soil depth as a random factor with a normal error distribution.

The full models used in hypothesis tests were therefore: (1) Proportion of roots = shaft location + soil depth + shaft location: soil depth; and (2) Soil concentration (Ca, $\mathrm{Mg}, \mathrm{K}, \mathrm{P}, \mathrm{pH}, \mathrm{OM}$ or $\mathrm{CEC})=$ shaft location + soil depth + shaft location: soil depth.

In the models, a plus sign $(+)$ denotes the addition of a variable to the model whereas a colon(:) means a statistical interaction between variables. Error distribution was Binomial and Normal for models (1) and (2), respectively.

\section{RESULTS}

The density of nests in our study area was $0.9 \mathrm{ha}^{-1}$ in the unburned plot and $0.6 \mathrm{ha}^{-1}$ in the burned plot, comprising a total area covered by nest mounds of $1.3 \%$ and $1.1 \%$ respectively. The mean size of the nests sampled was similar in the unburned and the burned plot $(64 \pm 13$ and $56 \pm 23 \mathrm{~m}^{2}$ respectively). All three nests in the unburned plot were active whereas the nests in the burned plot had low activity, although nest activity was not directly measured.

Frequent burning over long periods (every $2 \mathrm{y}$ for $12 \mathrm{y}$ in this case) was negatively related to concentrations of soil nutrients in ant nests. Concentrations of $\mathrm{Ca}$ and $\mathrm{P}$ in soil from ant nests in the burned plot were below our detection limit and the concentrations of $\mathrm{Mg}$ and $\mathrm{K}$ were low compared with ant nests in the unburned plot (Figures $1 \mathrm{a}, 1 \mathrm{c}$ and 2a, 2c). There was no significant difference in nutrient concentrations, organic matter or $\mathrm{pH}$ in non-nest soils between the burned and non-burned plot.

In contrast, ant nests from the unburned plot were associated with strong modifications of soil nutrient concentrations compared with non-nest soil or ant nests in 


\section{burned plot}

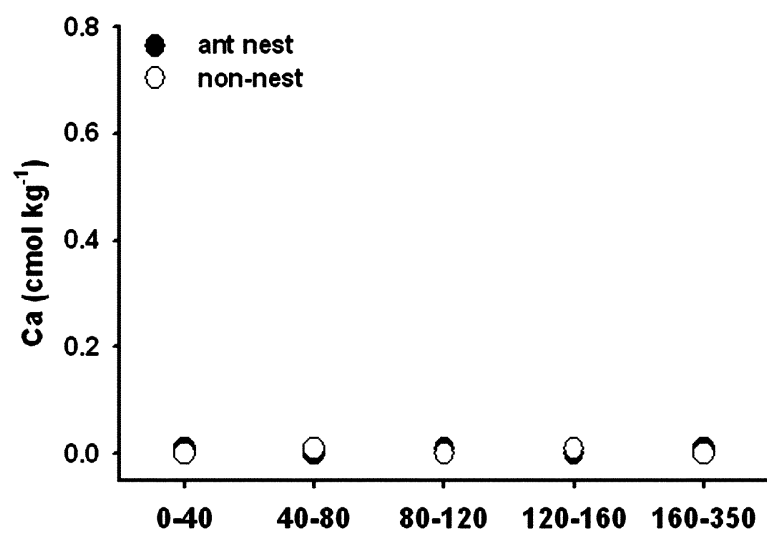

(a)

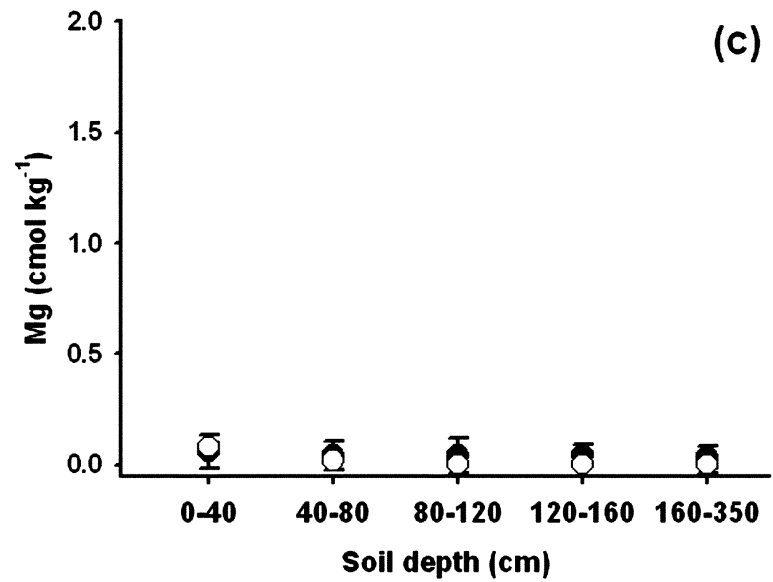

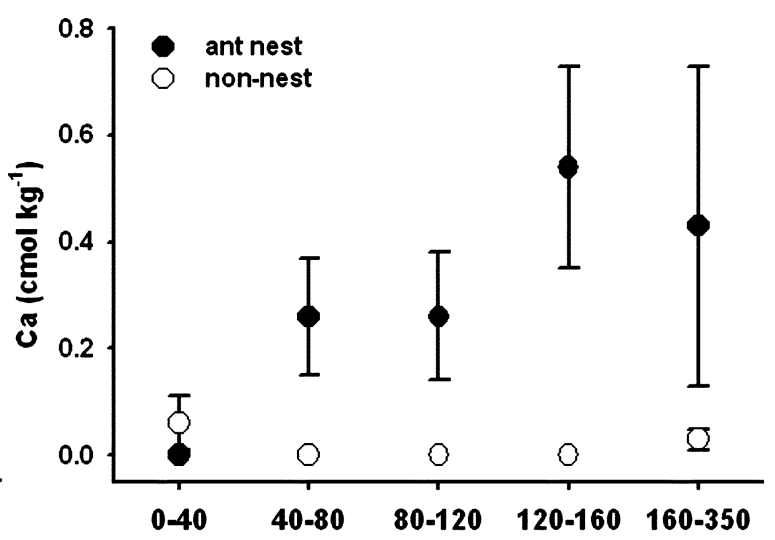

unburned plot

(b)

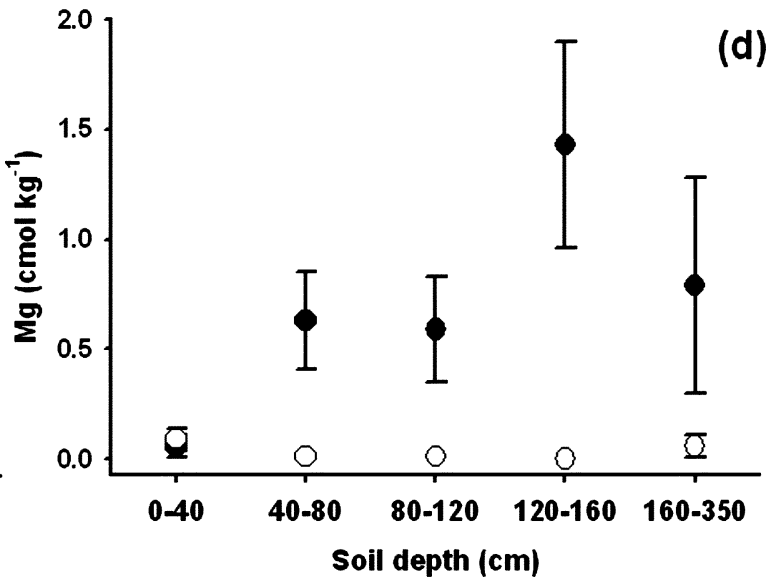

Figure 1 Soil availability of exchangeable cations $\mathrm{Ca}$ and $\mathrm{Mg}$ (mean $\pm \mathrm{SE}$ ) at several depths in ant nests and non-nests areas in plots that were successively burned every 2 y for over 12 y (a and c); or protected of burning since 1974 (b and c). Open symbols are non-nest soil (control) and black symbols are nest soil.

the burned plot (Figure 1b, $1 \mathrm{~d}$ and 2b, 2d). The interaction between shaft location and soil depth was significant for $\mathrm{Ca}, \mathrm{Mg}, \mathrm{P}, \mathrm{K}, \mathrm{pH}$, organic matter and $\mathrm{CEC}(\mathrm{P} \leq$ 0.01). With exception of the top $40 \mathrm{~cm}$, the values of $\mathrm{Ca}$ (Figure 1b), and $\mathrm{Mg}$ (Figure 1d) were significantly higher in these ant nests than anywhere else $\left(\mathrm{F}_{3,127}=16.4\right.$, $\mathrm{P}<0.001$ and $\mathrm{F}_{3,127}=19.8, \mathrm{P}<0.001$, respectively). Similar results were found for $\mathrm{K}\left(\mathrm{F}_{3,127}=38.6, \mathrm{P}<0.001\right)$ and $\mathrm{P}\left(\mathrm{F}_{3,127}=18.6, \mathrm{P}<0.001\right.$, Figure $2 \mathrm{~b}$ and $\left.2 \mathrm{~d}\right)$. There was a 6-50-fold increase in the concentrations of these nutrients at several depths. Soil $\mathrm{pH}$ was significantly different among ant nests $\left(\mathrm{F}_{3,6}=53.1, \mathrm{P}<0.001\right)$, all values were within the range of the latosol studied (Figure $3 \mathrm{a}-\mathrm{b}$ ). There was significant soil organic matter (SOM) accumulation in soils from ant nests compared with nonnest soils at depths below $40 \mathrm{~cm}$ in both plots $\left(\mathrm{F}_{3,6}=17.5\right.$, $\mathrm{P}<0.001$ ) (Figure $3 \mathrm{c}-\mathrm{d}$ ). However, SOM concentrations in nests from the burned plot were lower than in nests from the unburned plot. Similar results were found for cation exchange capacity $(\mathrm{CEC})\left(\mathrm{F}_{3,6}=13.1, \mathrm{P}<0.001\right)$ (Figure 3e-f).

Transects from shafts of ant nests were occupied with more roots than non-nest shafts at depths below 40 $\mathrm{cm}\left(\mathrm{F}_{3,43}=63.2, \mathrm{P}<0.001\right)$. At these depths, roots of woody plants were predominant. There was no significant difference in root density between the burned and unburned plot $\left(\mathrm{F}_{3,6}=0.13, \mathrm{P}>0.05\right)$, indicating that nests of both plots had the same effect on root density (Figure $4 a-b)$. In general, transects in shafts of ant nests had $60 \%$ of its squares occupied with roots whereas transects from non-nest shafts had only $30 \%$ of roots in the squares.

\section{DISCUSSION}

Leaf-cutting ants create high-nutrient patches in the cerrado by increasing soil fertility in areas protected from 


\section{burned plot}
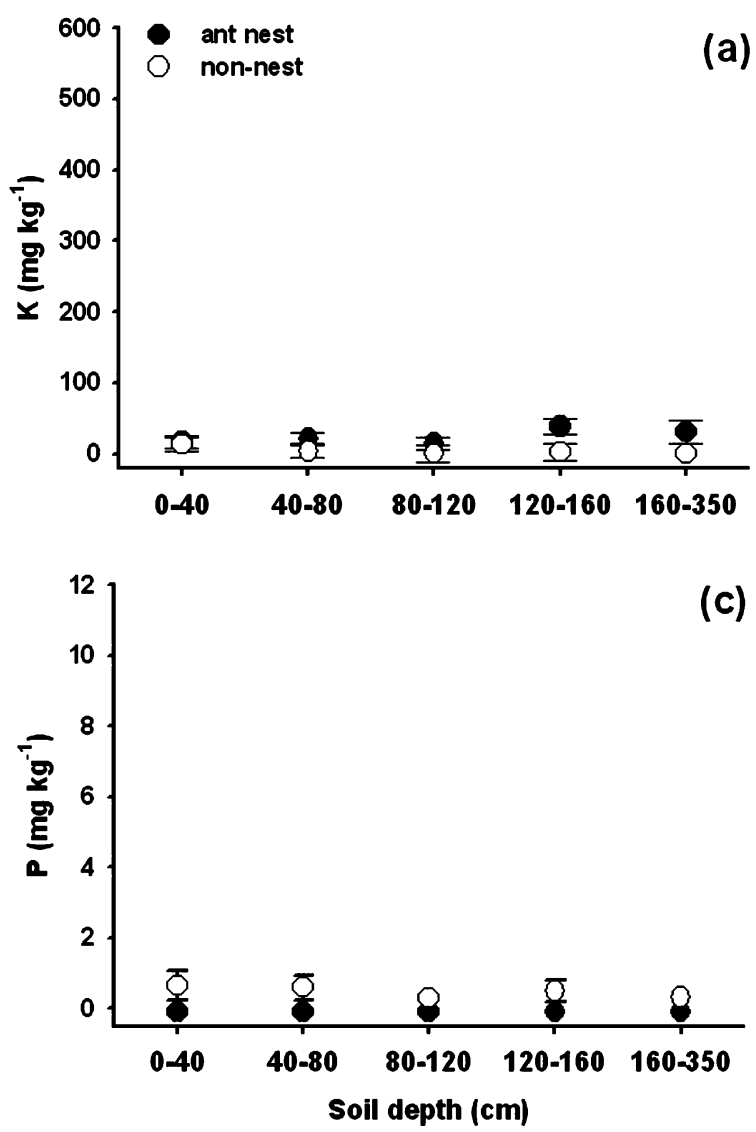

unburned plot
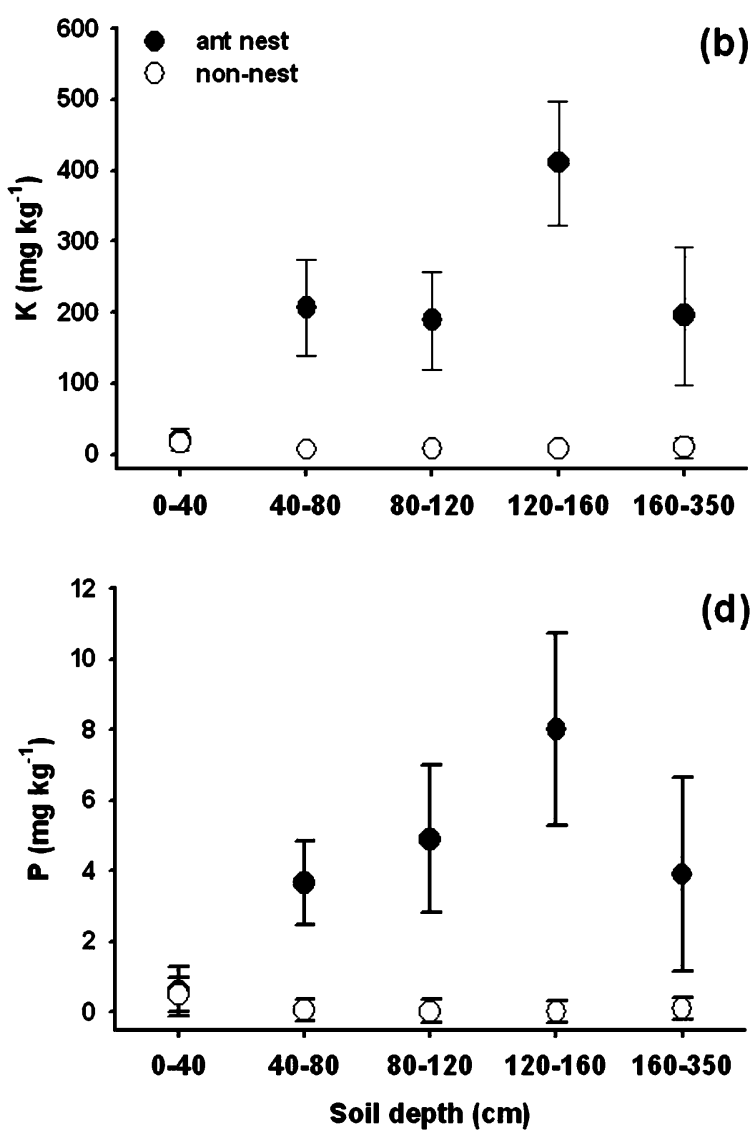

Figure 2 Soil availability (mean \pm SE) of $\mathrm{K}$ and $\mathrm{P}$ at several depths in ant nests and non-nests areas in plots that were successively burned (a and c) or protected from burning ( $b$ and d). Open symbols are non-nest soil (control) and black symbols are nest soil.

fire. In areas subjected to frequent fires, however, the effect of ant nests on nutrient accumulation was practically annulled through depletion of the concentrations of soil nutrients, cation exchange capacity and organic matter.

The increased root density inside ant nests in both burned and unburned plots indicates that ant nests are favourable patches for root growth and woody-plant establishment. As root density was similar within all ant nests, it is likely that nests from burned areas have been suitable patches for nutrient acquisition by surrounding plants. An alternative explanation for increased root density and changes in soil is colony founding after plant establishment or in areas of higher soil fertility. Several studies, however, suggest that differences between soils of ant nest and surrounding soils result from the activity of ant workers rather than a combination of initial conditions and subsequent worker modification (Dostál et al. 2005, Wagner et al. 2004). Besides, the success of colony establishment is higher in vegetation gaps and disturbed areas than protected ones (Vasconcelos \& Cherret 1995, Wirth et al. 2007), suggesting that plant colonization occurs commonly after the establishment of leaf-cutting ant nests. Thus, the differences in root density and soil nutrient concentrations between nest soil and non-nest soil in our study probably results, at least in part, from ant activity.

Although the negative effect of fire was confirmed, it is not clear, from our results, why soil macronutrient availability in ant nests from the burned plot was negatively affected. There are at least three possible explanations: first, as we found a high density of coarse roots (and probably the density of fine roots is also high) in ant nests from the burned plot, the soil nutrients in these sites could be reduced due to a likely high assimilation of nutrients by plants during successive post-fire recover (Batmanian \& Haridasan 1985, van de Vijver et al. 1999). If it is true, this could lead to a depletion of soil nutrients in these nests, overcoming the mineralization rate through organic matter deposition. In the long term, nutrient concentrations could be reduced to values similar to the control soil. Moutinho et al. (2003) found increases of up to 50-fold in fine-root biomass in Atta nests compared 
burned plot
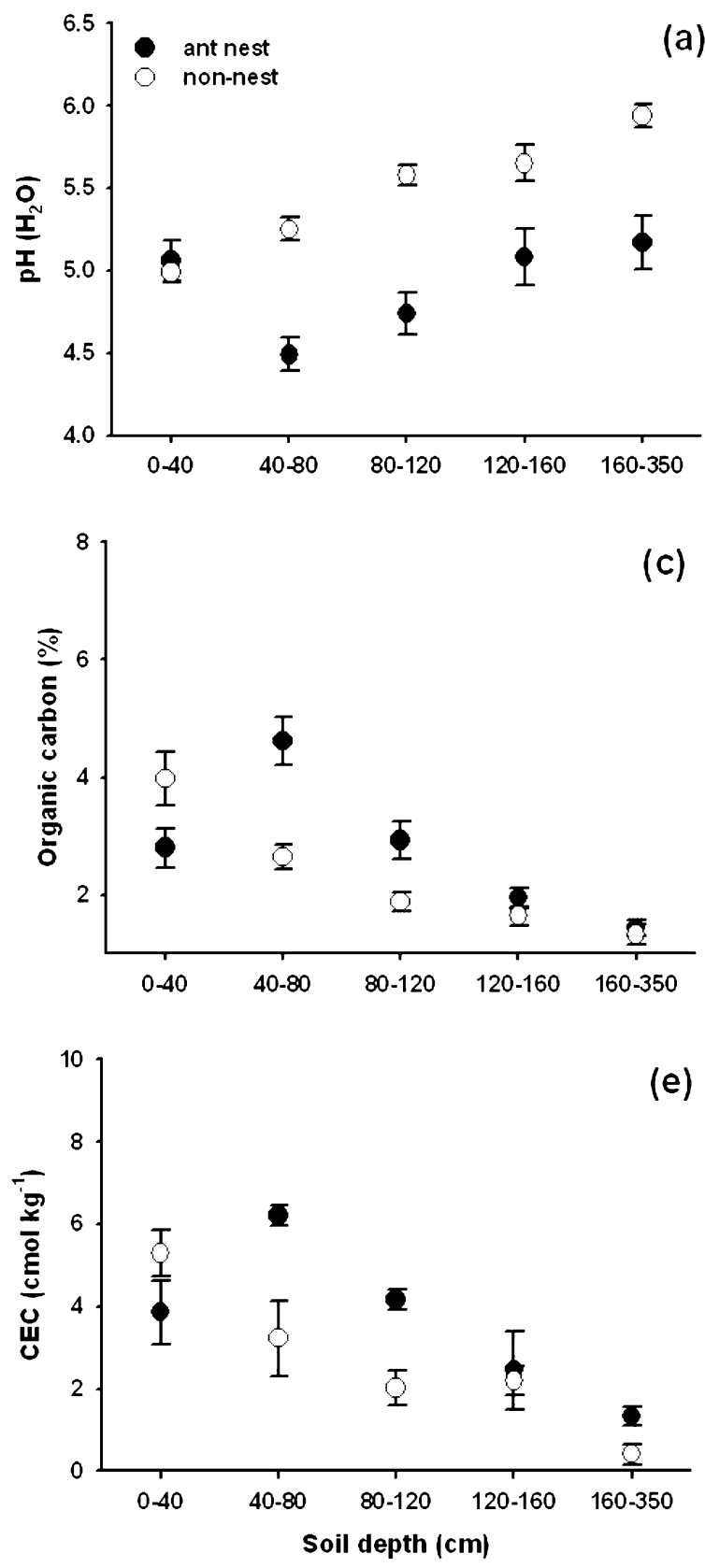

unburned plot
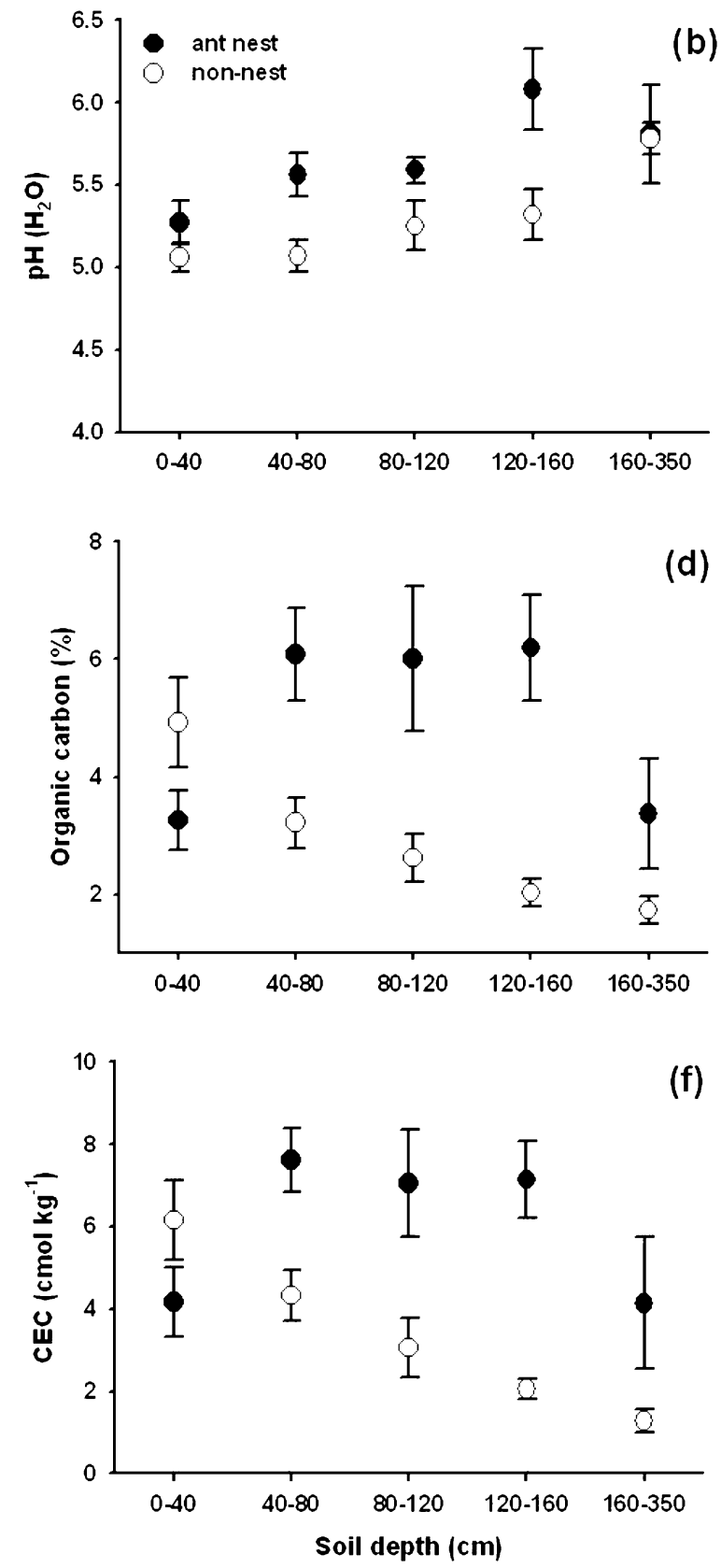

Figure 3 Soil pH, organic matter and cation exchange capacity (CEC) (mean \pm SE) at several depths in ant nests and control areas which were successively burned every 2 y for over 12 y (a, c and e) or protected of burning since 1974 (b, d and f). Open symbols are non-nest soil (control) and black symbols are nest soil.

with non-nest soil and suggested that proliferation of fine roots in nest soil was in response to lower resistance to penetration and increased nutrient availability. Second, the low concentrations of SOM and nutrients inside ant nests in the burned plot suggest reduced foraging activity of the ants. Burning has negative effects on the vegetation, such as tree mortality and reduced species diversity (Eiten 1972, Moreira 2000), which could decrease the range of species harvested by leaf-cutting ants, affecting the development of nests located in burned areas (Araújo et al. 2004). Species diversity and abundance of woody plants in our study site were similar in the burned and unburned plot (Moreira 2000) thus the range of plant species consumed by ants in both plots may not differ.

Finally, the possibility that nest maintenance (i.e. gallery excavation, soil inversion) was affected in the 
burned plot

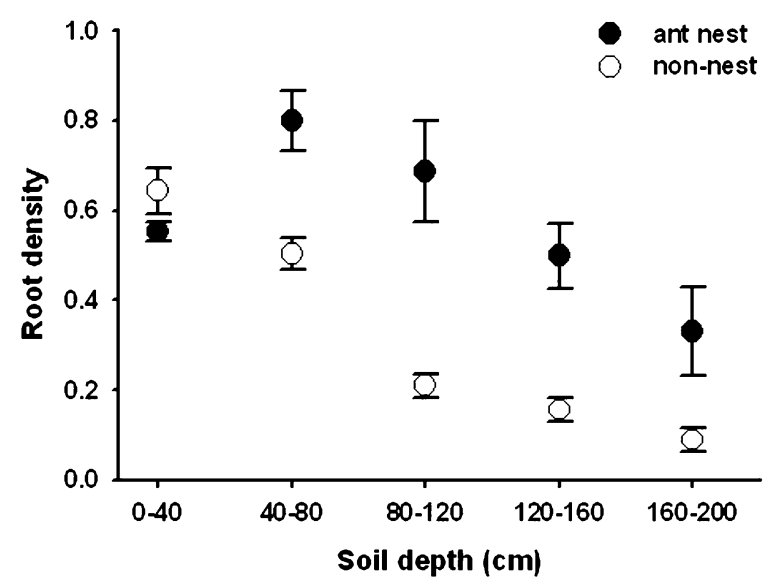

(a)

unburned plot

(b)

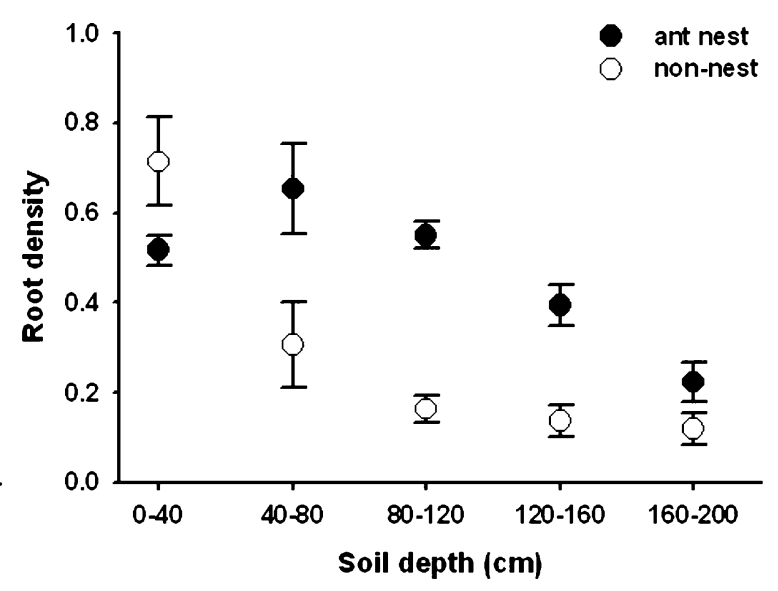

Figure 4 Vertical root density (the proportion of a shaft wall covered with roots) inside nest and non-nest shafts (mean \pm SE) which were successively burned every 2 y for over 12 y (a) or protected of burning since 1974 (b). Open symbols are non-nest shafts (control) and black symbols are ant nest shafts.

burned nests cannot be excluded. Therefore, soil material from chambers could lose nutrients through leaching in nests with low activity. Hence, if nests in the burned plot are somewhat inactive and ants did not replenish the nutrients at the same rates as in the unburned plot, it is likely that root density is due to changes in soil texture more than nutrient availability. Active nests of Lasius flavus, for example, had higher soil nutrient concentrations than abandoned nests or surrounding soil in grasslands (Dostál et al. 2005).

In contrast, the increased nutrient concentrations in ant nests in the unburned plot suggest an important role of Atta colonies in generating high-nutrient patches in cerrado habitats when fire disturbance is low or absent. Brazilian latosols are naturally deficient in many limiting nutrients such as $\mathrm{Ca}$, however, $\mathrm{P}$ is most limiting because of immobilization through adsorption to soil clay particles (Andrade et al. 2003). We found that leaf-cutting ant nests act as biological sources of $\mathrm{P}$ and $\mathrm{Ca}$ in latosols covered by cerrado vegetation. Availability of $\mathrm{P}$ and $\mathrm{Ca}$ through ant nests was reported in recent studies that consistently indicated direct nutrient uptake by plants surrounding ant nests (Sousa-Souto et al. 2007, Sternberg et al. 2007). High concentrations of $\mathrm{Mg}$, Ca and $\mathrm{OM}$ in the topsoil were previously reported for other systems (Farji-Brener \& Silva 1995, Haines 1978, Moutinho et al. 2003). As root biomass is commonly higher inside than outside ant nests, it is likely that ant nests in burned areas should lead to post-fire colonization by pioneer plants through facilitation of root establishment. Facilitated succession of plants by leaf-cutting ants was indeed found in a Venezuelan savanna (Farji-Brener \& Silva 1995).

In this study nests of the leaf-cutting ant $A$. laevigata have evidently changed soil chemical properties and the changes have enhanced root density. Although we found a lower concentration of soil nutrients in nests from the burned area, we believe that there was a causal relationship between root density and nutrient enrichment through nest activities. Hence, we think that these findings are not caused by preferences of ants for areas with high root density or high nutrient concentrations. Despite the low density of ant nests in our study site, compared with other areas (Araújo et al. 1997, Moutinho et al. 2003, Wirth et al. 2007), the importance of $A$. laevigata for cerrado vegetation seems high if we consider the large colony size of this species and that their influence may extend well beyond the area that is covered by nest mounds. For example, trees within a radius of $11 \mathrm{~m}$ from the nest mounds are affected by the nest through nutrient assimilation (Sternberg et al. 2007). Thus, the negative effect of leaf-cutting ants on plant biomass through herbivory (Lugo et al. 1973) would, at least in part, be diminished by nutrient availability for plants close to A. laevigata nests. In the presence of fire, however, the cumulative effect of persistent losses of nutrients through burning and herbivory by leaf-cutting ants may decrease site productivity in the long term.

\section{ACKNOWLEDGEMENTS}

The authors wish to thank to Danival Souza, Túlio Gomes, Thyago Silva, Felipe Suci and Ricardo Solar for field assistance, Maria Iracema Gonzales and Heloisa Miranda for allowing us to perform this research in the experimental area, Eraldo Lima, Arne Janssen (Visiting Teacher [PVE] from CAPES, Brazil) for helpful suggestions and English revision. The Nature Conservancy (project 
024/2003) and Conselho Nacional de Desenvolvimento Científico e Tecnológico (CNPq) are thanked for financial support.

\section{LITERATURE CITED}

ANDRADE, F. V., MENDONÇA, E. S., ALVAREZ, V., V.H.\& NOVAIS, R.F. 2003. Adição de ácidos orgânicos e húmicos em latossolos e adsorção de fosfato. Revista Brasileira de Ciências do Solo 27:1003-1011.

ARAÚJO, M. S., DELLA LUCIA, T. M. C. \& MAYHÉ-NUNES, A. J. 1997. Levantamento de Attini (Hymenoptera, Formicidae) em povoamento de Eucalyptus na região de Paraopeba, Minas Gerais, Brasil. Revista Brasileira de Zoologia 14:323-328.

ARAÚJO, M. S., DELLA LUCIA, T. M. C. \& PICANÇO, M. C. 2004. Impacto da queima da palhada da cana-de-açúcar no ritmo diário de forrageamento de Atta bisphaerica Forel (Hymenoptera, Formicidae). Revista Brasileira de Zoologia 21:33-38.

BATMANIAN, G. J. \& HARIDASAN, M. 1985. Primary production and accumulation of nutrients by the ground layer community of cerrado vegetation of central Brazil. Plant and Soil 88:437-440.

CHERRETT, J. M. 1989. Leaf-cutting ants. Pp. 473-488 in Lieth H. \& Werger M. J. A. (eds.). Tropical rain forest ecosystems: biogeographical and ecological studies. Elsevier, Amsterdam.

COUTINHO, L. M. 1978. O conceito de cerrado. Revista Brasileira de Botânica 1:17-23.

COUTINHO, L. M. 1984. Aspectos ecológicos da saúva no cerrado. A saúva, as queimadas e sua possível relação na ciclagem de nutrientes minerais. Boletim de Zoologia da Universidade de São Paulo 8: 1-9.

CRAWLEY, M. J. 2002. Statistical computing: an introduction to data analysis using S-Plus. John Wiley \& Sons, Chichester. 761 pp.

DOSTÁL, P., BREZNOVÁ, M., KOZLICKOVÁ, V., HERBEN, T. \& KOVÁR, P. 2005. Ant-induced soil modification and its effect on plant belowground biomass. Pedobiologia 49: 127-137.

EITEN, G. 1972. The cerrado vegetation of Brazil. Botanical Review 38:201-341.

EMBRAPA (Empresa Brasileira de Pesquisa Agropecuária) 1997. Manual de métodos de análise de solo. 2 ed. CNPS, Rio de Janeiro. 212 pp.

EMBRAPA (Empresa Brasileira de Pesquisa Agropecuária) 1999. Sistema brasileiro de classificação de solos. CNPS, Brasília. 412 pp.

FARJI-BRENER, A. G. \& ILLES, A. E. 2000. Do leaf-cutting ant nests make "bottom-up" gaps in neotropical rain forests? A critical review of the evidence. Ecology Letters 3:219-227.

FARJI-BRENER, A. G. \& MEDINA, C. 2000. The importance of where to dump the refuse: seed banks and fine roots in nests of the leaf-cutting ants Atta cephalotes and Atta colombica. Biotropica 31:120-126.

FARJI-BRENER, A. G. \& SILVA, J. 1995. Leaf-cutting ants and forest groves in a tropical parkland savanna of Venezuela: facilitated succession? Journal of Tropical Ecology 11:651-669.

GARRETTSON, M., STETZEL, J. F., HALPERN, B. S., HEARN, D. J., LUCEY, B. T. \& MCKONE, M. J. 1998. Diversity and abundance of understory plants on active and abandoned nests of leaf-cutting ants (Atta cephalotes) in a Costa Rican rain forest. Journal of Tropical Ecology 14:17-26.
HAINES, B. 1978. Element and energy flows through colonies of the leaf-cutting ant, Atta colombica, in Panama. Biotropica 10:270277.

LOBRY DE BRUYN, L. A. \& CONACHER, A. J. 1990. The role of termites and ants in soil modification: a review. Australian Journal of Soil Research 28:55-93.

LUGO, A., FARNWORTH, E., POOL, D., JEREZ, P. \& KAUFMAN, G. 1973. The impact of the leaf-cutting ant Atta colombica on the energy flow of a tropical wet forest. Ecology 54:1292-1301.

MIRANDA, A. C., MIRANDA, H. S., DIAS, I. F. O. \& DIAS, B. F. S. 1993. Soil and air temperatures during prescribed cerrado fires in Central Brazil. Journal of Tropical Ecology 9:313-320.

MOREIRA, A. G. 2000. Effects of fire protection on savanna structure in Central Brazil. Journal of Biogeography 27:10211029.

MOUTINHO, P., NEPSTAD, D. C. \& DAVIDSON, E. A. 2003. Influence of leaf-cutting ant nests on secondary forest growth and soil properties in Amazônia. Ecology 84:1265-1276.

RAO, M. 2000. Variation in leaf-cutter ant (Atta sp.) densities in forest isolates: the potential role of predation. Journal of Tropical Ecology 16:209-225.

SCHOEREDER, J. H. \& COUTINHO, L. M. 1990. Fauna e estudo zoossociológico das espécies de saúvas (Formicidae, Attini) em duas regiões de cerrado do estado de São Paulo. Revista Brasileira de Entomologia 35:229-236.

SOUSA-SOUTO, L., SCHOEREDER, J. H \& SCHAEFER, C. E. 2007. Leafcutting ants, seasonal burning and nutrient distribution in Cerrado vegetation. Austral Ecology 32:758-765.

STERNBERG, L. S. L., PINZON, M.C., MOREIRA, M. Z., MOUTINHO, P., ROJAS, E. I \& HERRE, E. A. 2007. Plants use macronutrients accumulated in leaf-cutting ant nests. Proceedings of the Royal Society of London 274:315-321.

VAN DE VIJVER, C. A. D. M., POOT, P. \& PRINS, H. H. T. 1999. Causes of increased nutrient concentrations in post-fire regrowth in an East African savanna. Plant and Soil 214:173-185.

VASCONCELOS, H. \& CHERRETT, J. M. 1995. Changes in leaf-cutting ant populations (Formicidae, Attini) after the clearing of mature forest in Brazilian Amazonia. Studies on Neotropical Fauna and Environment 30:107-113.

VERCHOT, L. V., MOUTINHO, P. R. \& DAVIDSON, E. A. 2003. Leaf-cutting ant (Atta sexdens) and nutrient cycling: deep soil inorganic nitrogen stocks, mineralization, and nitrification in Eastern Amazonia. Soil Biology and Biochemistry 35:12191222.

WAGNER, D., JONES, J. B. \& GORDON, D. M. 2004. Development of harvester ant colonies alters soil chemistry. Soil Biology and Biochemistry 36:797-804.

WIRTH, R., MEYER, S. T., ALMEIDA, W. R., ARAUJO, M. V., BARBOSA, V. S. \& LEAL, I. R. 2007. Increasing densities of leaf-cutting ants (Atta spp.) with proximity to the edge in a Brazilian Atlantic forest. Journal of Tropical Ecology 23:501-505.

WOOD, T. G. \& SANDS, W. A. 1978. The role of termites in ecosystems. Pp. 245-292 in Brian M. V. (ed.). Production ecology of ants and termites. Cambridge University Press, Cambridge. 